\title{
Article
}

\section{Investigating tree foliar preference by the earthworms Aporrectodea longa and Allolobophora chlorotica in reclaimed and loam soil}

Ashwood, F, Butt, Kevin Richard, Doick, KJ and Vanguelova, El

Available at http://clok.uclan.ac.uk/16181/

Ashwood, F, Butt, Kevin Richard ORCID: 0000-0003-0886-7795, Doick, KJ and Vanguelova, El (2017) Investigating tree foliar preference by the earthworms Aporrectodea longa and Allolobophora chlorotica in reclaimed and loam soil. Applied Soil Ecology, 110 . pp. 109-117. ISSN 0929-1393

It is advisable to refer to the publisher's version if you intend to cite from the work. http://dx.doi.org/10.1016/j.apsoil.2016.10.007

For more information about UCLan's research in this area go to http://www.uclan.ac.uk/researchgroups/ and search for <name of research Group>.

For information about Research generally at UCLan please go to http://www.uclan.ac.uk/research/

All outputs in CLoK are protected by Intellectual Property Rights law, including Copyright law. Copyright, IPR and Moral Rights for the works on this site are retained by the individual authors and/or other copyright owners. Terms and conditions for use of this material are defined in the policies page. 
1 Investigating tree foliar preference by the earthworms Aporrectodea longa and

2 Allolobophora chlorotica in reclaimed and loam soil

3 Frank Ashwood ${ }^{\mathrm{a}^{*}}$, Kevin R. Butt ${ }^{\mathrm{b}}$, Kieron J. Doick ${ }^{\mathrm{a}}$ and Elena I. Vanguelova ${ }^{\mathrm{a}}$

4

5 a Forest Research, Alice Holt Lodge, Farnham, Surrey, GU10 4LH

6 b University of Central Lancashire, Preston, Lancashire, PR1 2HE

7

$8 \quad *$ Correspondence:

9 Dr Frank Ashwood

10 Soil Sustainability Research Group

11 Forest Research

12 Alice Holt Lodge

13 Farnham, Surrey, United Kingdom

14 francis.ashwood@forestry.gsi.gov.uk 
Abstract

Afforestation can improve the delivery of ecosystem services from reclaimed landfill sites. Tree health is a key determinant of ecosystem service delivery, and is directly impacted by soil quality; which is driven by biological processes in the soil, reliant on leaf litter inputs to function. Different tree species have different litter quality, affecting the degree to which they support biological processes in soils and the development of abundant and diverse soil faunal communities. In recognition of their key role in improving soil structure and fertility - key attributes of soil quality, earthworms have often been the subject of research as a part of land reclamation, and these organisms have displayed preferences for specific types of leaf litter. This work utilised a choice chamber design to measure the foliar material palatability of two tree species used in land restoration (Alnus cordata and Acer platanoides) as a food source for two common European earthworm species (Aporrectodea longa and Allolobophora chlorotica), and the effect of a reclaimed soil quality on earthworm growth, survival and feeding preferences. The research revealed that both earthworm species initially preferred the foliar material of $A$. cordata over $A$. platanoides, with the leaves of the latter requiring higher degradation to become palatable to earthworms. The consumption of fresh leaves showed these are a suitable food source for earthworms in choice chamber experiments, which historically have instead relied on senescent leaf litter. Finally, high survival rates of both $A$. longa and $A$. chlorotica in the reclaimed soil treatment, in addition to consumption of leaf material of two tree species now widely used on reclaimed landfill sites, demonstrated that these earthworm species are suitable candidates for inoculation to reclaimed land.

\section{Keywords}




\section{Introduction}

The afforestation of reclaimed land, such as former landfill, can provide improved biodiversity, contribute toward climate change mitigation and adaptation, and improve the delivery of ecosystem services from the site (Bullock et al., 2011). In restored woodland, as with natural woodland, a key source of organic matter addition to the soil is from deposited leaf material (Lukac and Godbold, 2011). Tree species differently influence soil quality and soil faunal population development through the quality and quantity of their leaf and root litter (Swift et al., 1979a; Pigott, 1989; Muys et al., 1992; Reich et al., 2005; Rajapaksha et al., 2013). It is therefore of value, when planning woodland restoration, to understand whether the tree species planted are likely to provide litter which enables and encourages soil faunal communities to establish, thus supporting soil development and ecosystem service provision (Kibblewhite et al., 2008; Rajapaksha et al., 2013). Certain tree species, such as Alnus cordata and Acer platanoides are recommended for planting on reclaimed or industrial land, based on their tolerance for high soil pH and dry soil conditions (Hibberd, 1986). There is, however, currently a paucity of knowledge regarding the interaction between these two non-native tree species and native UK soil biota, making these important tree species to investigate further and compare to previous research with similar native species (Rajapaksha et al., 2013).

In recognition of their role in improving soil structure and fertility, earthworms have been the subject of research during land reclamation for over 50 years, e.g. (van Rhee, 1969; Curry and Cotton, 1983; Curry, 1988; Butt et al., 1995). Earthworm-mediated mineralisation of organic matter, improvement in nutrient availability, and subsequent improvements in plant growth, are likely to be greater in nutrient-poor soils (Jana et al., 2010). It has been demonstrated that 
certain earthworm species can distinguish between, and may show a preference for, specific types of leaf litter (Darwin, 1881; Satchell and Lowe, 1967). The chemical composition of litter appears to strongly influence earthworm selectivity, in particular aspects such as the C:N ratio and the content of nitrogen, calcium, lignin and polyphenols (Satchell and Lowe, 1967; Hendriksen, 1990). Earthworm preference has been observed for litter decomposed by microorganisms and fungus, which is more palatable over fresh litter material (Satchell and Lowe, 1967; Wright, 1972; Cooke and Luxton, 1980; Cooke, 1983). However, there is also an indication that the higher nitrate content in dried green leaves can make these a superior quality food for earthworms than dried, senescent and weathered leaves (Butt, 2011a), yet little research has been conducted on this.

To date, the majority of laboratory-based earthworm feeding preference studies have either looked at how earthworm species respond to non-tree leaf material, or how the welldocumented earthworm species L. terrestris responds to tree litter (Satchell and Lowe, 1967; Doube et al., 1997; Neilson and Boag, 2003). A notable exception is a choice-chamber study by Rajapaksha et al. (2013), which investigated how four European earthworm species respond to the litter of a set of common temperate tree species (common alder, common ash, silver birch, sweet chestnut and sycamore) and an exotic Eucalyptus species, using standard Kettering loam soil as a substrate. However, these results do not necessarily represent the activity of the same earthworms in woodland on reclaimed landfill sites, where alternative tree species and more inhospitable soil materials are likely to be present. Additionally, and to the authors knowledge, there is currently no information on how a combination of anecic and endogeic earthworm species perform in choice chamber feeding experiments, which would provide results more comparable to field conditions, where these 
84 two ecological groups often coincide (Lavelle, 1983). Whilst senesced leaf litter has been used

85 as an experimental food source in previous choice chamber experiments (e.g. Rajapaksha et

86 al., 2013), due to seasonal unavailability of such material this experiment adopted the use of

87 freshly collected tree foliar material. Since green tree leaves have not been investigated in

88 earthworm choice chambers to date, this provided the opportunity to gather novel

89 information on this material as a food source for earthworms.

90 Therefore, the objectives of this study were to:

91 1. Measure the foliar material palatability of two tree species used in land restoration as a food source for earthworms, and influence on earthworm mass and survival,

2. Measure the effect of reclaimed soil on earthworm mass, survival and foliar selection behaviour, compared to a control (Kettering loam) soil,

3. Obtain data on the above from a combination of endogeic and anecic earthworm species relevant to landfill conditions. 


\section{Materials and Methods}

\subsection{Choice chamber and experimental design}

This experiment utilised the choice chamber design described by Rajapaksha et al. (2013), which is a modified version of Doube et al. (1997) and Rief et al. (2012). This design allows for earthworm food preference to be regularly monitored and quantified by removal of feeding tubes, with minimal disturbance to the central chamber and resident earthworms. The addition of soil to the central chamber rather than moist filter paper (e.g. Doube et al., 1997) provides more natural environmental conditions for endogeic and anecic earthworm species, and in this experiment also allowed for comparison between two soil types. This experiment investigated tree foliar preference by two species of earthworm; Allolobophora chlorotica (endogeic) and Aporrectodea longa (anecic); both as monocultures and as a combined species treatment. Two soil treatments were investigated; Kettering loam and reclaimed soil. Five trays (replicates) were set up for each combination of soil treatment and earthworm culture (5 replications $X 2$ soils $X 3$ earthworm combinations $=30$ trays in total). Six food tubes containing leaf material from two different tree species litter (e.g. three tubes per tree species) were arranged alternatingly around each tray, and the average mass loss of these per tree species per tray was measured.

The choice chamber design consisted of a circular aluminium foil tray $(0.16 \mathrm{~m}$ diameter and $0.03 \mathrm{~m}$ depth) with standard Eppendorf tubes (0.01 $\mathrm{m}$ diameter and $0.04 \mathrm{~m}$ depth) spaced equally around the choice chamber and embedded into the tray walls as food containers (Figure 1a). To enable the tubes to be affixed to the choice chambers and allow earthworm access to tube contents, the caps were removed from the tubes and a hole of approximately $0.01 \mathrm{~m}$ diameter was drilled in each cap (Rajapaksha et al., 2013). An equally-sized hole was 


\section{[INSERT FIGURE 1]} $\mathrm{Mg}$.

[INSERT TABLE 1]

then made in the wall of the choice chamber and the caps placed on the inside of the hole, enabling the tubes to be attached on the outside wall of the choice chamber and held in place by the caps (Figure 1b). This enables the tubes to be removed from the caps and replaced without disturbing the contents of the main chamber.

Prior to experimentation, empty Eppendorf tubes were affixed to the choice chambers, and each choice chamber was filled with a soil treatment at $25 \%$ moisture content (Figure 2 ). The two soil treatments were: sterile (heat-treated) Kettering loam topsoil (Boughton Loam, Kettering, UK), which is a standard substrate for use in general earthworm experiments and choice chamber experiments (Butt et al., 1994b; Rajapaksha et al., 2013), or sterilised anthropogenic soil materials taken from an afforested reclaimed landfill site in Rainham, UK (Nat. Grid Ref TQ 52572 83192). Sterilised field-collected reclaimed soils were sieved to remove materials $>4 \mathrm{~mm}$, then frozen at $-5{ }^{\circ} \mathrm{C}$ for 7 days to destroy native earthworms and other potential competitors and predators (Butt, 2011b). The average chemical composition of both soil treatments at the start of the experiment is provided in Table 1 . The reclaimed soil treatment possessed significantly higher $\mathrm{pH}$, conductivity, total $\mathrm{C}$, organic carbon, organic matter (\%), C: $\mathrm{N}$ ratio and total $\mathrm{K}(\%)$ than the Kettering loam treatment. The loam soil possessed significantly higher total $\mathrm{N}(\%)$ and $\mathrm{Ca}$, and both soils had similar levels of $\mathrm{Na}$ and 
Earthworms were then randomly selected, had masses determined and were allocated to the choice chambers according to the species combination treatments, and sprayed with water. This experiment investigated the leaf material preference of two earthworm species: $A$. longa (anecic) and $A$. chlorotica (endogeic) with initial individual mean initial masses of 2.30 (SE \pm 0.11 ) and 0.26 (SE \pm 0.01$) \mathrm{g}$, respectively. Each earthworm species was introduced to separate choice chambers in the following numbers, according to treatment; monoculture of $A$. longa (4), monoculture of $A$. chlorotica (20), or a mixed culture of $A$. longa and $A$. chlorotica ( 2 and 10, respectively). These numbers were selected for similar earthworm biomass across choice chambers independent of earthworm treatment, and to ensure a quantifiable rate of leaf material removal within the short timeframe of the experiment. All earthworms were collected from agricultural pasture at Walton Hall Farm, Preston, UK (Nat. Grid Ref: SD 55050 28100), via digging and hand-sorting of soil. To prevent earthworm escape during the experiment, choice chambers were covered with a sheet of aluminium foil held in place by an elastic band. Small holes were made in the foil with a mounted needle to allow for air circulation whilst maintaining soil moisture content. All choice chambers were then stored in total darkness in a temperature-controlled incubator at $15^{\circ} \mathrm{C}$ for a period of 24 hours, to allow earthworms to equilibrate to the experimental conditions.

Leaf materials from two tree species were selected for use in this experiment; these were $A$. platanoides and Alnus cordata. Fresh leaf materials of both species were collected from trees at Ingrebourne Hill Community Woodland (the reclaimed site from which soil materials were obtained). These were separately air-dried and ground using a MAGIMIX 4150W food processor, then sieved to obtain leaf particles of $1-2 \mathrm{~mm}$ size. Particle size has been shown to influence earthworm selection of food material (Lowe and Butt, 2003), and this size range 
was chosen to prevent such issues. A sub-sample of both tree species leaf materials was retained for chemical composition analysis. Fresh Eppendorf tubes were individually labelled, had masses determined and were filled with dried and sieved leaf particles of either tree species (between 0.2 - $0.3 \mathrm{~g}$ per tube), and had mass re-determined. The leaf-filled tubes were then topped-up with water and left to soak for two hours, and inverted on absorbent paper for five minutes to drain excess water. Tubes then had mass re-determined to obtain the wet starting mass of the leaf materials. These tubes were then assigned to specific choice chambers and used to replace the empty Eppendorf tubes, thus marking the start of the experiment. Three feeding tubes for each species leaf material were placed in alternating positions around each choice chamber, with a total of six tubes per choice chamber (Figure 2). Throughout the experiment, choice chambers were maintained in a temperaturecontrolled incubator at $15^{\circ} \mathrm{C}$, in total darkness.

\subsection{Measurements}

Leaf material removal from feeding tubes was measured every three days, by determining the mass loss (\%) of each tube. Earthworm preference was associated with leaf removal. Following mass recording, each tube was then re-attached in the same location. During measurement periods, each choice chamber had its foil lid removed and was inspected for signs of dead earthworms, with any mortalities recorded and the remains removed. Soil moisture content was maintained in each choice chamber by spraying each with an equal amount of water during inspection. The experiment was terminated after 27 days, or earlier for any choice chamber when all leaf material had been removed from the feeding tubes. At termination of the experiment, earthworm survival and final masses were recorded for each choice chamber. 
Statistical analysis was performed using the freeware statistical software R, version 3.2.2.

"Fire Safety" and the R Studio desktop software, version 0.99.486 (R Core Team, 2015;

RStudio Team, 2015). Data were first tested for normality using the Shapiro-Wilk test, which is suited to smaller sample sizes (in this case $n=5$ ). All leaf removal data for each species and soil treatment had a normal distribution. To identify feeding preference midway through the which $50 \%$ total leaf material was removed from choice chambers in each tray, as per

The choice chambers enabled accurate monitoring of earthworm feeding behaviour, with experiment, and a generally similar pattern for all species combinations across soil treatments.

Table 2 shows earthworm performance across treatments at the start and at termination of the experiment. After 27 days, 100\% survival was recorded for $A$. longa across all treatments. A. chlorotica had $98-99 \%$ survival in reclaimed soil, but survival was much lower $(35-46 \%)$ in the loam treatment. A. chlorotica lost mass across all treatments (range of -4.0 to $-41.0 \%$ ), $A$. longa lost mass in the monoculture loam treatment combination $(-1.89 \%$ loss $)$ and gained mass across all other treatment/species combinations ( +15.5 to $+20.0 \%$ gain). 
212 Figure 3 illustrates the pattern of leaf litter removal from choice chambers by all three

213 earthworm species combinations supplied with $A$. cordata and $A$. platanoides foliar material

214 over 27 days for both soil treatments. All three species combinations showed a clear initial

215 preference for $A$. cordata leaf material over that of $A$. platanoides. After 12 days, the rate of

216 A. platanoides leaf material removal by all earthworm species rapidly increased under both

217 soil treatments. Despite the large difference in survivorship between $A$. chlorotica in the loam

218 and reclaimed soils (35 and 99\%, respectively, Table 2), there was little difference in final litter

219 removal between treatments (see also Figure 3). Foliar material removal by $A$. chlorotica 220 monoculture was linear throughout the experiment, although far reduced compared with $A$.

221 longa monoculture and the mixed species treatment.

For A. longa monoculture in the loam soil treatment, at 15 days (the point of $50 \%$ total leaf removal) the amount of $A$. cordata was significantly less than $A$. platanoides (ANOVA, $F(1,8)$ $=25.66, p<0.001$, see Table 3). In the reclaimed soil treatment, $A$. longa displayed a similar pattern of litter removal, which was also statistically significant (ANOVA, $F(1,8)=9.77, p=$ 0.014). There was also a significant effect of soil on leaf material removal (two-way repeat measures ANOVA, $F(1,16)=6.39, p=0.022)$. The combined species treatment showed $a$ similar, although less pronounced leaf preference result to $A$. longa monocultures and results were not statistically significant. A. chlorotica showed a clear trend of litter removal, although $50 \%$ was not reached at termination of the experiment after 27 days. As with the other earthworm species treatments, $A$. chlorotica consumed more $A$. cordata than $A$. platanoides leaf material, in both soil treatments. 
Table 3 displays the remaining leaf litter (\%) at 50\% of total litter removal for each series of

235

236

237

238

239

240

241

[INSERT TABLE 5]

\section{[INSERT TABLE 3]}

\section{[INSERT TABLE 4]}

choice chambers in the experiment, the point of which varied with earthworm species combinations, but did not vary across soil treatments; A. longa (15 days) A. chlorotica (50\% not removed by experiment termination at 27 days), and mixed species ( 21 days). At the point of $50 \%$ removal, $A$. longa monocultures and the mixed earthworm species treatment showed a clear preference for $A$. cordata over A. platanoides.

The results of chemical analysis of leaf material at the start and end of the experiment (bulked material remaining in tubes after 27 days, $n=1$ ) are given in Table 4 . Both tree species leaf material showed an increase in total $\mathrm{N}, \mathrm{P}, \mathrm{Ca}$ and $\mathrm{Mg}(\%)$ at termination of the experiment, and a reduction in $\mathrm{C}: \mathrm{N}$ ratio and total $\mathrm{K}(\%)$. At the outset, $A$. cordata leaf material had higher total N (\%) and lower C:N ratio and Ca (\%) than A. platanoides leaves.

Using the results for the loam control soil treatment presented in Table 3, the leaf foliar removal data of $A$. longa and $A$. chlorotica can be compared to the litter preference data for these earthworm species presented by Rajapaksha et al. (2013). Table 5 shows earthworm preference for A. cordata and A. platanoides compared with the leaf litter preference list of Rajapaksha et al. (2013). 


\subsection{Earthworm combinations}

All three earthworm treatments demonstrated a preference for the foliar material of $A$.

cordata over that of $A$. platanoides. The anecic species $A$. longa displayed rapid removal of

foliar material - in monoculture this species removed an average of $4.1 \mathrm{mg}$ leaf material/g fresh weight of earthworm/day, compared to $1 \mathrm{mg}$ leaf material/g fresh weight of earthworm/day displayed by A. chlorotica in monoculture. Little data exists in the literature regarding an average OM consumption rate for these two earthworm species - however an accepted average range of 12-17 $\mathrm{mg}$ grass litter/g fresh mass of earthworm/day has been reported for six temperate grassland earthworm species (van Rhee, 1963; Curry and Schmidt, 2007). In woodland habitats $A$. longa feeds directly on leaf litter material on the soil surface, pulling the material into vertical burrows in the soil (Satchell, 1983). By comparison, the endogeic earthworm species $A$. chlorotica, which primarily feeds on organic matter within the soil, demonstrated a much slower removal of leaf material; yet this species also showed a preference at the outset of the experiment for A. cordata over A. platanoides foliar material. Similar trends in relative rates of litter removal from choice chambers was observed by Rajapaksha et al. (2013) for different earthworm species representatives of the same two ecological groupings: L. terrestris (anecic) and A. caliginosa (endogeic). This was attributed to the different feeding behaviours and the differences in physical size between the two species. The large difference in survivorship between A. chlorotica in the loam and reclaimed soils resulted in little difference in final litter removal between treatments, indicating that minimal feeding was taking place by the surviving $A$. chlorotica in both soil treatments. This suggests that the food quality or type provided is not particularly suited to this species and/or ecological group. This is likely due to the geophagous nature of this species, and as such, 
future feeding experiments involving endogeic geophagous species should take this into consideration. As also found by Rajapaksha et al. (2013), the current choice chamber design was better suited to larger, litter-feeding earthworm species than smaller, soil-feeding earthworms.

Earthworm body size and food particle size may have also influenced leaf foliar material removal. Neilson and Boag (2003) observed a low removal of food by $A$. chlorotica during a choice experiment, and found that for the six earthworm species investigated, the mass of food removed was positively correlated with earthworm body size. Food particle size has also been demonstrated to influence intake by earthworms, with reduced particle size generally being of greater benefit to smaller earthworms; however the effects of food size on growth and reproduction may be both species and life-stage specific (Boyle, 1990; Lowe and Butt, 2003).

The addition of an anecic earthworm species might be expected to provide benefits to an endogeic earthworm species, through comminution and incorporation of leaf litter into the soil where it can be more easily consumed (e.g. Lowe and Butt, 2003). In controlled laboratory experiments, Butt (1998) and Lowe and Butt (1999) investigated the influence of inter- and intra-specific interactions on earthworm growth rates and reproductive output. Results indicated that earthworm mass was generally negatively affected by the presence of other species, however the severity of the negative influence was related to the extent of niche overlap between the species (Lowe and Butt, 1999). They suggested that the greatest competitive interaction effects were present between species representing the same ecological group; findings which support observations by Edwards and Lofty (1978) of negative correlations between ecological grouping and the field densities of four UK 
earthworm species. Lowe and Butt (2002a) found that inter- and intra-specific interactions negatively influenced earthworm growth, maturation and fecundity; and this was again directly related to the extent of niche overlap between pairings. A notable exception was found for A. chlorotica, which exhibited enhanced growth and cocoon production in the presence of $A$. longa. It was concluded that the results of earthworm species interactions cannot be predicted simply based on ecological groupings (Lowe and Butt, 2002a).

In this experiment, $A$. longa demonstrated greater increase in final mass when in combination with $A$. chlorotica, compared with A. longa monoculture, across both soil types. This supports the findings of Lowe and Butt (2002a), whereby mature anecic L. terrestris exhibited greatest masses when paired with endogeic earthworm species. However, the mechanism by which endogeic earthworms might have a positive influence on anecic earthworm mass is difficult to identify. It may be the case that the greater $A$. longa final mass change is the result of reduced intra-specific competition between the two species of different ecological groupings for the limited food resources of the close experimental environment (Lowe and Butt, 1999).

The lack of any clear change in A. chlorotica mass between combined species and monoculture suggests that $A$. longa did not provide a positive inter-specific relationship to $A$. chlorotica, e.g. by facilitating A. chlorotica feeding. Lowe and Butt (2002a) identified that juveniles of one ecological group may have a "niche overlap" and subsequent negative interaction with members of another ecological grouping. However, the earthworms used here were all adults, and as such this cannot explain the lack of inter-specific interaction observed on A. chlorotica. Interestingly, the mixed earthworm species treatment was almost as effective as the $A$. longa monoculture at consuming leaf litter. This would seem to suggest that $A$. chlorotica acted in leaf removal alongside $A$. longa, however this does not appear to 
be reflected in earthworm mass data for this species. The results of earthworm mass and leaf removal rate for the combined earthworm treatment suggest that these species can co-exist as an inoculum, and therefore represent an appropriate species combination for inoculation into field experiments on reclaimed landfill.

\subsection{Leaf palatability}

The initial preference for $A$. cordata foliar material over that of $A$. platanoides indicates greater quality and palatability of this tree species leaf material to the earthworm species in the experiment, particularly $A$. longa. Previous studies have helped to identify the chemical and physical parameters of litter which influence litter palatability to earthworms. The chemical composition of litter appears to strongly influence earthworm selectivity, in particular aspects such as the $\mathrm{C}: \mathrm{N}$ ratio and the content of nitrogen, calcium, lignin and polyphenols (Satchell and Lowe, 1967; Hendriksen, 1990; Reich et al., 2005; Rajapaksha et al., 2013). Generally, higher $N$ and Ca content and a lower C:N ratio have been associated with increased palatability of leaf litter to earthworms (Reich et al., 2005; Rajapaksha et al., 2013). Current results generally fit this trend; at the start of the experiment, $A$. cordata foliar material had higher total $\mathrm{N}(\%)$ and lower C:N ratio and $\mathrm{Ca}(\%)$ content than that of $A$. platanoides. In a similar study, Rajapaksha et al. (2013) found that leaf litter from the least preferred tree species, sweet chestnut (Castanea sativa), demonstrated particularly low levels of nitrogen and calcium, and highest $\mathrm{C}: \mathrm{N}$ ratio of all tree species investigated: alder $(A$. glutinosa), common ash (F. excelsior), silver birch (Betula pendula), sweet chestnut (Castanea sativa), sycamore (Acer pseudoplatanus), and an exotic Eucalyptus species (Eucalyptus nitens). However, the preferred tree species $A$. cordata had lower calcium content than the less-preferred A. platanoides, which suggests that calcium content may be less important for 
leaf palatability, compared to other parameters such as $\mathrm{N}$ or $\mathrm{C}: \mathrm{N}$ ratio. Other factors may affect leaf palatability to earthworms besides those already discussed, such as lignin and tannin content (Hendriksen, 1990). Whilst these were not analysed in the present study, literature indicates that $A$. cordata and $A$. platanoides foliar material possess a lignin content of 14.9 ( $\mathrm{SE} \pm 1.8) \%$ and 10.2 (SE \pm 0.3 ) \%, respectively (Dromenach et al., 1994; Hejcmanová et al., 2014). Using these figures, it appears that foliar lignin content was unlikely to explain palatability to the earthworms in this study, as also found by Hendriksen (1990) for tree litter palatability to detritivorous earthworms. Hobbie et al. (2014) found the leaf litter of $A$. platanoides possesses a cellulose and hemicellulose content of $17.8 \%( \pm 0.3)$ and $16.5 \%( \pm$ $0.2)$, however no data could be found in the literature for these variables on $A$. cordata foliar or litter material, for comparison. It is strongly recommended that these are assessed in future feeding preference studies, as increased cellulose content has been associated with higher C:N ratio and therefore a reduction in leaf palatability to earthworms; with a need for a period of weathering to overcome this (Dickinson, 2012).

It has been suggested that litter selection by earthworms can be affected by the state of leaf litter decomposition or weathering (Satchell and Lowe, 1967; Hendriksen, 1990). Earthworms have been shown to prefer decomposed litter by fungal and bacterial colonisation over fresh litter (Satchell and Lowe, 1967; Wright, 1972; Cooke and Luxton, 1980; Cooke, 1983; Hendriksen, 1990). Over the course of this experiment, microbial activity may have affected leaf foliar chemical composition and palatability to earthworms. Both tree species leaf litter showed increase in total $\mathrm{N}, \mathrm{Ca}$ and $\mathrm{Mg}(\%)$ at termination of the experiment, and a reduction in $\mathrm{C}: \mathrm{N}$ ratio and $\mathrm{K}(\%)$. Microbial colonisation of decaying leaf litter leading to litter decomposition has been positively related to increase in $\mathrm{N}$ concentration and negatively 
This represents a positive change in the key chemical parameters which are thought to effect

372 leaf palatability, and likely explains the sudden increase in A. platanoides foliar material removal by all earthworm treatments mid-way through the experiment (since there was still A. cordata leaf material available at this point, the increased consumption of $A$. platanoides material was unlikely due to lack of other food resources).

The use of green leaf foliar material was shown to successfully support earthworm growth and survival, particularly so for the anecic earthworm species $A$. longa. This supports the findings of Butt (2011a), who used dried green Betula pendula leaves as feedstock for $L$. terrestris and found that switching from dried senesced leaves to green leaves during a long term experiment resulted in increased $L$. terrestris mass and significantly increased cocoon production. This was attributed to the larger nitrate content in green leaves enabling more rapid protein synthesis for growth and reproduction.

\subsection{Soil treatments}

Soil type did not appear to influence earthworm leaf species preference, with the same trend of leaf selection observed for both soil types and earthworm species. There was, however, a slower rate of leaf consumption observed in the reclaimed soil treatment for all earthworm species combinations treatments. This may be linked to higher soil organic matter content in the reclaimed soil (5.9\%) compared with the loam (4.7\%), which may have enabled increased geophagous feeding rather than direct leaf removal in both $A$. chlorotica and A. longa (Lowe and Butt, 2002b). Typically, soil materials on newly reclaimed landfill sites are unlikely to have high levels of organic matter content (Bending et al., 1999). The levels observed in the reclaimed soils used in this experiment may represent the accidental inclusion of root and 
other dead plant material (and therefore greater levels of labile carbon for earthworm utilisation), since the soil was collected from a re-vegetated 10 -year-old reclaimed landfill site. In this experiment, $A$. longa demonstrated $100 \%$ survivorship in both soil treatments, whilst A. chlorotica showed higher survival in reclaimed soil compared to Loam (98\% and 35\% respectively). Both earthworm species displayed tolerance for soil $\mathrm{pH}$ of $>8.0$, which is above that typically recommended for these species, and higher than previous research suggest $A$. longa may tolerate (Baker and Whitby, 2003; Lowe and Butt, 2005). Overall, both earthworm species demonstrated high tolerance of the reclaimed soil used in this experiment, supporting the findings of Butt et al. (2004) who recorded sustainable populations of $A$. longa and $A$. chlorotica over a period of ten years following inoculation into reclaimed landfill. In the Kettering loam treatment, $A$. chlorotica showed low survivorship and a decrease in final individual mass. This was surprising, since this soil material has been widely successfully used and is recommended as a standard soil for earthworm-focussed laboratory experiments (Butt et al., 1994b; Lowe and Butt, 2005; Rajapaksha et al., 2013). Earthworm survival and activity is greatly influenced by abiotic factors, in particular soil temperature and moisture content; however in this experiment these were maintained at optimal levels and are therefore unlikely to explain the $A$. chlorotica mortality observed (Lowe and Butt, 2005). Starvation of this geophagous species is unlikely to be the cause of death, since the soil organic matter content of the loam used in this experiment (4.7\%) was only marginally lower than that used in other experiments (5\%) (Butt et al., 1994a; Rajapaksha et al., 2013). It may be the case that the loam soils used in this experiment had become contaminated in some manner during storage prior to the experiment. One proposed explanation for the high rate of $A$. chlorotica mortality is a negative influence of the decomposition of any early mortalities (e.g. from 
stress/adverse soil conditions upon transport to trays) upon the survival of surrounding earthworms in a closed microcosm. There is currently no discussion of this potentially antagonistic effect in the literature, likely due to the difficulty in distinguishing this from other negative environmental conditions triggering earthworm mortality.

\section{Conclusions}

The choice chamber experiment described in this study clearly demonstrated that green leaf material is a suitable food source for the earthworm species investigated. Different tree leaf quality impacts on litter palatability to earthworms with $A$. cordata foliar material of better quality than that of $A$. platanoides, which needed more time to undergo some degradation before it became palatable to earthworms. The earthworm species $A$. longa and A. chlorotica demonstrated tolerance (survival and mass increase) of the reclaimed soil used in this experiment, as well as a moderate consumption rate (in the case of $A$. longa) of the leaf material of trees common to reclaimed landfill sites. As such these earthworm species represent suitable candidates for inoculation to reclaimed landfills, where suitable conditions prevail.

\section{Acknowledgements}

The authors would like to thank the Forestry Commission England's Thames Beat team for providing funding and resources to support this research. We would also like to thank Jack Forster for helpful advice on statistical analysis.

\section{References}

Baker, G. H. and Whitby, W. (2003). Soil pH preferences and the influences of soil type and temperature on the survival and growth of Aporrectodea longa (Lumbricidae). Pedobiologia, 47 (5-6), p.745-753. 
Bending, N. A. D., McRae, S. G. and Moffat, A. J. (1999). Soil-forming Materials: Their Use in Land Reclamation. London: DETR.

Boyle, K. E. (1990). The ecology of earthworms (Lumbricidae) in grassland on reclaimed cutover peatland and their impact on soil physical properties and grass yield. Unpublished Ph. D. thesis, National University of Ireland. Cited in Edwards, CA (ed) Earthworm Ecology. St. Lucie Press, Boca Raton, JOUR, p.37-64.

Bullock, J. M., Aronson, J., Newton, A. C., Pywell, R. F. and Rey-Benayas, J. M. (2011). Restoration of ecosystem services and biodiversity: Conflicts and opportunities. Trends in Ecology \& Evolution, 26 (10), article, p.541-549.

Butt, K. R. (1998). Interactions between selected earthworm species: A preliminary, laboratory-based study. Applied Soil Ecology, 9 (1-3), p.75-79.

Butt, K. R. (2011a). Food quality affects production of Lumbricus terrestris (L.) under controlled environmental conditions. Soil Biology and Biochemistry, 43 (10), p.2169-2175.

Butt, K. R. (2011b). The earthworm inoculation unit technique: development and use in soil improvement over two decades. In: Karaca, A. (ed.), Biology of Earthworms, Berlin: SpringerVerlag, p.87-105.

Butt, K. R., Frederickson, J. and Morris, R. M. (1994a). Effect of earthworm density on the growth and reproduction of Lumbricus terrestris L. (Oligochaeta: Lumbricidae) in culture. Pedobiologia, 38, article, p.254-261.

Butt, K. R., Frederickson, J. and Morris, R. M. (1994b). The life cycle of the earthworm Lumbricus terrestris L. (Oligochaeta: Lumbricidae) in laboratory culture. European Journal of Soil Biology, 30 (2), article, p.49-54.

Butt, K. R., Frederickson, J. and Morris, R. M. (1995). An earthworm cultivation and soil inoculation technique for land restoration. Ecological Engineering, 4 (1), article, p.1-9.

Butt, K. R., Lowe, C. N., Frederickson, J. and Moffat, A. J. (2004). The development of sustainable earthworm populations at Calvert landfill site, UK. Land Degradation and Development, 15, article, p.27-36.

Cooke, A. and Luxton, M. (1980). Effect of microbes on food selection by Lumbricus terrestris. Revue d'Ecologie et de Biologie du Sol, 17 (3), JOUR, p.365-370.

Cooke, J. (1983). The effects of fungi on food selection by Lumbricus terrestris L. In: Satchell, J. E. (ed.), Earthworm Ecology, London: Chapman \& Hall, p.365-373.

Curry, J. P. (1988). The ecology of earthworms in reclaimed soils and their influence on soil fertility. In: Ecology of Earthworms, p.151-161.

Curry, J. P. and Cotton, D. C. F. (1983). Earthworms and land reclamation. In: Satchell, J. E. (ed.), Earthworm Ecology, London: Chapman \& Hall, p.215-228.

Curry, J. P. and Schmidt, O. (2007). The feeding ecology of earthworms - A review. Pedobiologia, 50, article, p.463-477.

Darwin, C. (1881). The Formation of Vegetable Mould, Through the Action of Worms, with Observations on their Habits. London: John Murray.

Dickinson, C. H. (2012). Biology of plant litter decomposition. Elsevier.

Doube, B. M., Schmidt, O., Killham, K. and Correll, R. (1997). Influence of mineral soil on the 
palatability of organic matter for lumbricid earthworms: a simple food preference study. Soil Biology and Biochemistry, 29 (3/4), p.569-575.

Dromenach, A.-M., Moiroud, A. and Jocteur-Monrozier, L. (1994). Leaf Carbon and Nitrogen Constituents of some Actinorhizal Tree Species. Soil Biol. Biochem, 26 (5), p.649-653.

Edwards, C. A. and Lofty, J. R. (1978). The influence of arthropods and earthworms upon root growth of direct drilled cereals. Journal of Applied Ecology, 15 (3), article, p.789-795.

Hejcmanová, P., Stejskalová, M. and Hejcman, M. (2014). Forage quality of leaf-fodder from the main broad-leaved woody species and its possible consequences for the Holocene development of forest vegetation in Central Europe. Vegetation History and Archaeobotany, 23 (5), p.607-613.

Hendriksen, N. B. (1990). Leaf litter selection by detritivore and geophagous earthworms. Biology and Fertility of Soils, 10 (1), p.17-21.

Hibberd, B. G. (1986). Forestry Commission Handbook 5: Urban Forestry Practice. London: HMSO.

Hobbie, S. E., Baker, L. A., Buyarski, C., Nidzgorski, D. and Finlay, J. C. (2014). Decomposition of tree leaf litter on pavement : implications for urban water quality. p.369-385.

Jana, U., Barot, S., Blouin, M., Lavelle, P., Laffray, D. and Repellin, A. (2010). Earthworms influence the production of above-and belowground biomass and the expression of genes involved in cell proliferation and stress responses in Arabidopsis thaliana. Soil Biology and Biochemistry, 42 (2), article, p.244-252.

Kibblewhite, M. G., Ritz, K. and Swift, M. J. (2008). Soil health in agricultural systems. Philosophical transactions of the Royal Society of London. Series B, Biological sciences, 363, p.685-701.

Lavelle, P. (1983). The structure of earthworm communities. In: Earthworm ecology, Springer, p.449-466.

Lowe, C. N. and Butt, K. R. (1999). Interspecific interactions between earthworms: A laboratory-based investigation. Pedobiologia, 43, article, p.808-817.

Lowe, C. N. and Butt, K. R. (2002a). Growth of hatchling earthworms in the presence of adults: interactions in laboratory culture. Biology and Fertility of Soils, 35 (3), article, p.204209.

Lowe, C. N. and Butt, K. R. (2002b). Influence of organic matter on earthworm production and behaviour: a laboratory-based approach with applications for soil restoration. European Journal of Soil Biology, 38 (2), article, p.173-176.

Lowe, C. N. and Butt, K. R. (2003). Influence of food particle size on inter- and intra-specific interactions of Allolobophora chlorotica (Savigny) and Lumbricus terrestris. Pedobiologia, 47 (5-6), p.574-577.

Lowe, C. N. and Butt, K. R. (2005). Culture techniques for soil dwelling earthworms: A review. Pedobiologia, 49 (5), article, p.401-413.

Lukac, M. and Godbold, D. L. (2011). Soil ecology in northern forests: a belowground view of a changing world. Cambridge: Cambridge University Press.

Muys, B., Lust, N. and Granval, P. (1992). Effects of grassland afforestation with different tree species on earthworm communities, litter decomposition and nutrient status. Soil 
Biology and Biochemistry, 24 (12), p.1459-1466.

Neilson, R. and Boag, B. (2003). Feeding preferences of some earthworm species common to upland pastures in Scotland. Pedobiologia, 47 (1), p.1-8.

Pigott, C. D. (1989). The growth of lime (Tilia cordata) in an experimental plantation and its influence on soil development and vegetation. Quarterly Journal of Forestry, 83 (1), JOUR, p.14-24.

R Core Team. (2015). R: A language and environment for statistical computing.

Rajapaksha, N. S. S., Butt, K. R., Vanguelova, E. I. and Moffat, A. J. (2013). Earthworm selection of Short Rotation Forestry leaf litter assessed through preference testing and direct observation. Soil Biology and Biochemistry, 67, article, p.12-19.

Reich, P. B., Oleksyn, J., Modrzynski, J., Mrozinski, P., Hobbie, S. E., Eissenstat, D. M., Chorover, J., Chadwick, O. A., Hale, C. M. and Tjoelker, M. G. (2005). Linking litter calcium, earthworms and soil properties: A common garden test with 14 tree species. Ecology Letters, 8 (8), p.811-818.

van Rhee, J. A. (1963). Earthworm activities and the breakdown of organic matter in agricultural soils. In: Doeksen, J. and van der Drift, J. (eds.), Soil Organisms: Proceedings of the Colloquium on Soil Fauna, Soil Microflora and their Relationships. North-Holland, Amsterdam: North-Holland Publishing Company, p.55-59.

van Rhee, J. A. (1969). Development of earthworm populations in polder soils. Pedobiologia, 9, article, p.133-140.

Rief, A., Knapp, B. A. and Seeber, J. (2012). Palatability of selected Alpine plant litters for the decomposer Lumbricus rubellus (Lumbricidae). PLOS ONE, 7 (9), p.1-7.

RStudio Team. (2015). RStudio: Integrated Development for $R$.

Satchell, J. E. (1983). Earthworm ecology in forest soils. In: Satchell, J. E. (ed.), Earthworm Ecology, London: Chapman \& Hall, p.161-170.

Satchell, J. E. and Lowe, D. G. (1967). Selection of leaf litter by Lumbricus terrestris. Progress in soil biology, p.102-119.

Swift, M. J., Heal, O. W. and Anderson, J. M. (1979a). Decomposition in terrestrial ecosystems. Oakland, California: University of California Press.

Swift, M. J., Heal, O. W. and Anderson, J. M. (1979b). Decomposition in terrestrial ecosystems. Oakland, California: University of California Press.

Wright, M. A. (1972). Factors governing ingestion by the earthworm Lumbricus terrestris (L.), with special reference to apple leaves. Annals of Applied Biology, 70 (2), JOUR, p.175188. 
557 Figure 1.

558
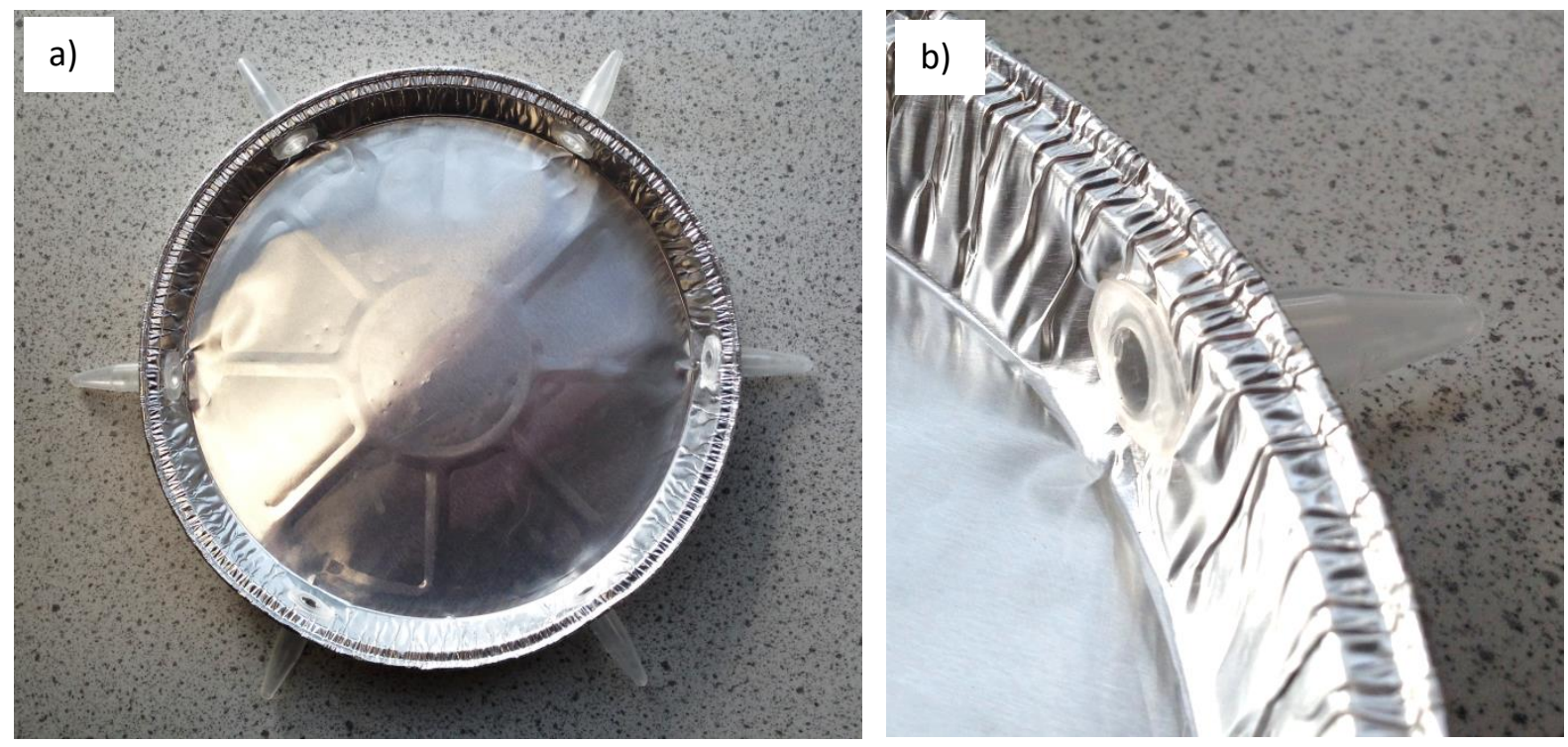
Table 1.

\begin{tabular}{lll}
\hline Parameter & \multicolumn{2}{l}{ Soil type } \\
\cline { 2 - 3 } & Kettering Loam & Reclaimed Soil \\
\hline $\mathrm{pH}\left(\mathrm{H}_{2} \mathrm{O}\right)$ & $7.85 \pm 0.03$ & $8.13 \pm 0.02^{* *}$ \\
Cond. $(\mu \mathrm{s} / \mathrm{cm})$ & $748.0 \pm 31.3$ & $1558.7 \pm 98.0^{* *}$ \\
Total $\mathrm{N}(\%)$ & $0.27 \pm 0.00$ & $0.21 \pm 0.00^{* * *}$ \\
Total C (\%) & $3.04 \pm 0.02$ & $4.56 \pm 0.09^{* * *}$ \\
$\mathrm{C}(\mathrm{Org})(\%)$ & $2.73 \pm 0.03$ & $3.41 \pm 0.04^{* * *}$ \\
$\mathrm{O} . \mathrm{M} .(\%)$ & $4.71 \pm 0.05$ & $5.88 \pm 0.07^{* * *}$ \\
$\mathrm{C}(\mathrm{org}): \mathrm{N}$ ratio & $10.01 \pm 0.11$ & $16.06 \pm 0.12^{* * *}$ \\
$\mathrm{~K}(\mathrm{mg} / \mathrm{kg})$ & $187.4 \pm 1.8$ & $460.8 \pm 1.4^{* * *}$ \\
$\mathrm{Ca}$ & $4324.1 \pm 3.3$ & $3933.4 \pm 64.6^{* *}$ \\
$\mathrm{Mg}$ & $119.8 \pm 0.2$ & $121.0 \pm 0.7$ \\
$\mathrm{Na}$ & $23.55 \pm 0.17$ & $19.65 \pm 0.51^{* *}$ \\
Texture & Clay loam & Sandy clay loam \\
\hline
\end{tabular}

560 

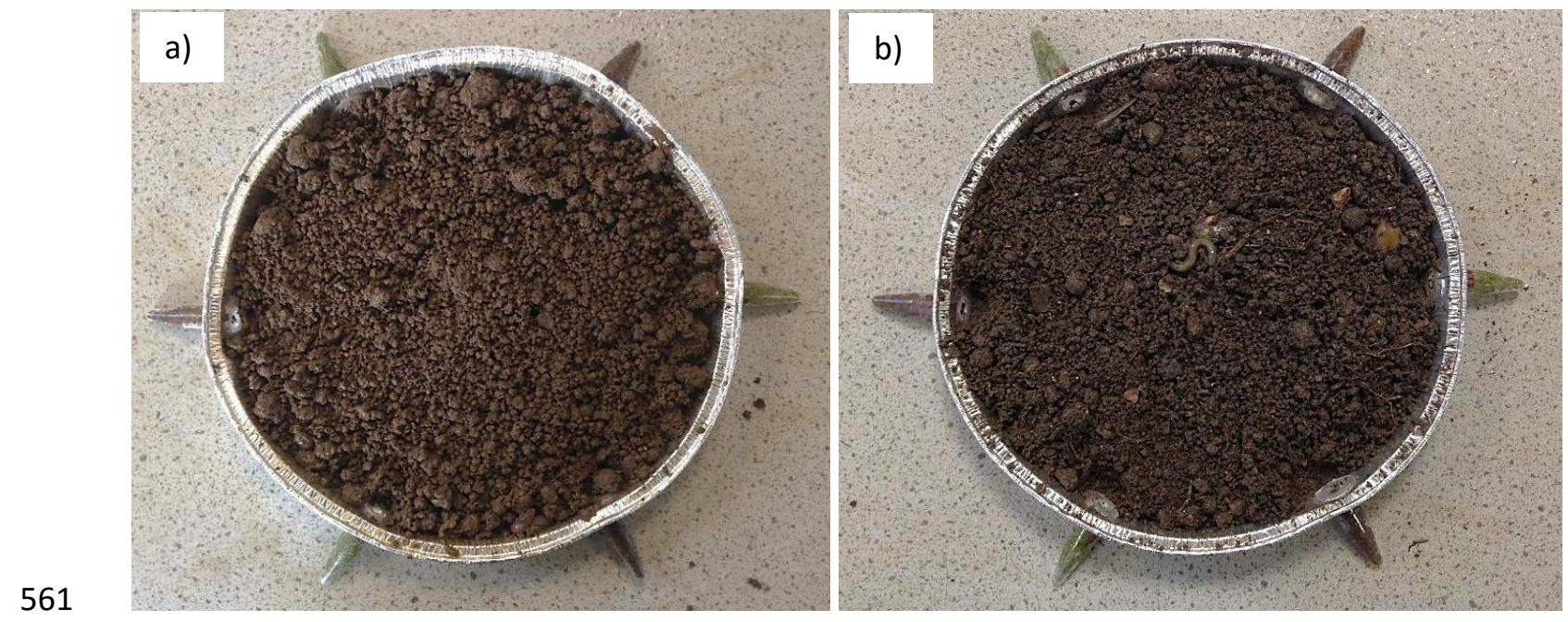

562 Figure 2.

563 
a)Aporrectodea longa monoculture

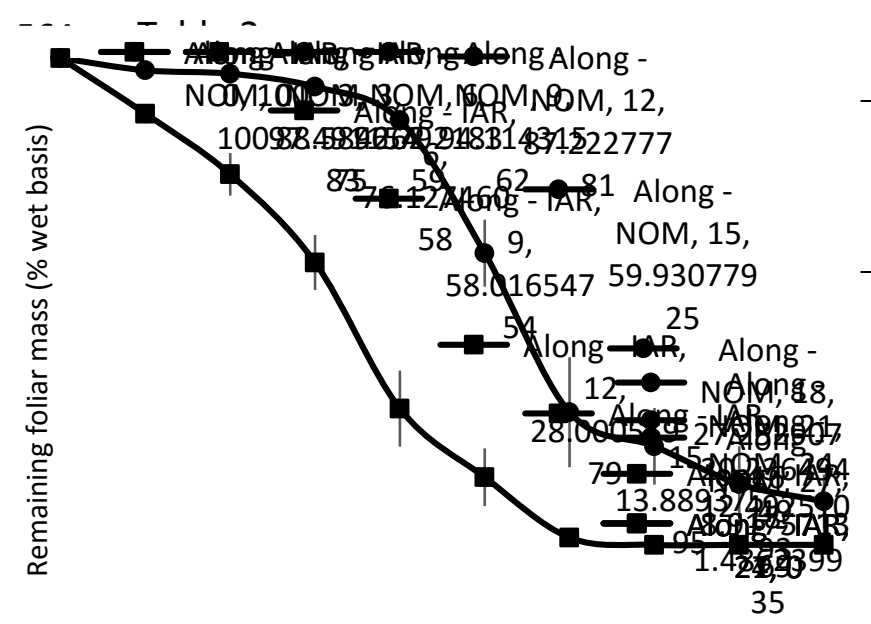

Time (days) b)

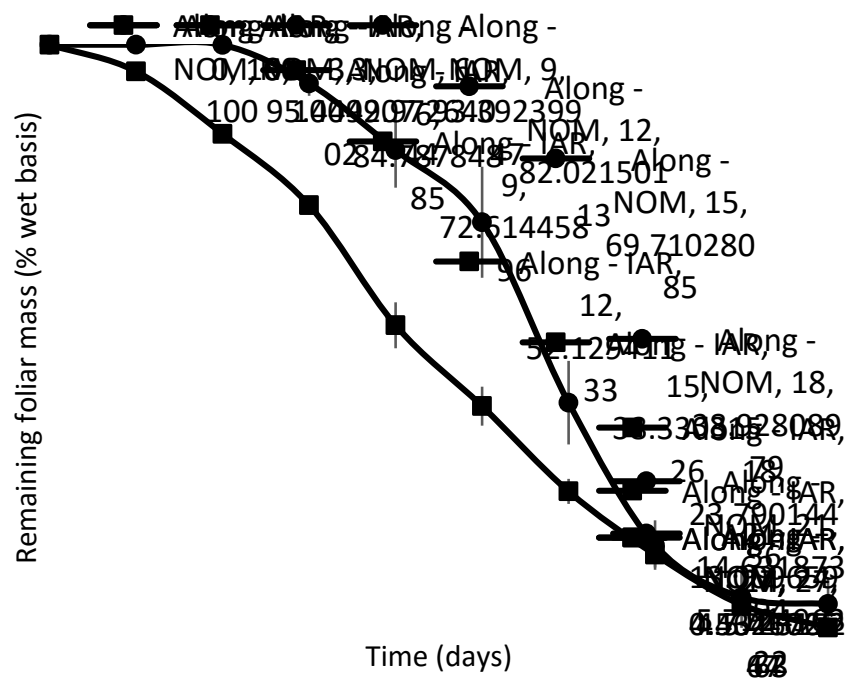


Allolobophora chlorotica monoculture

a)

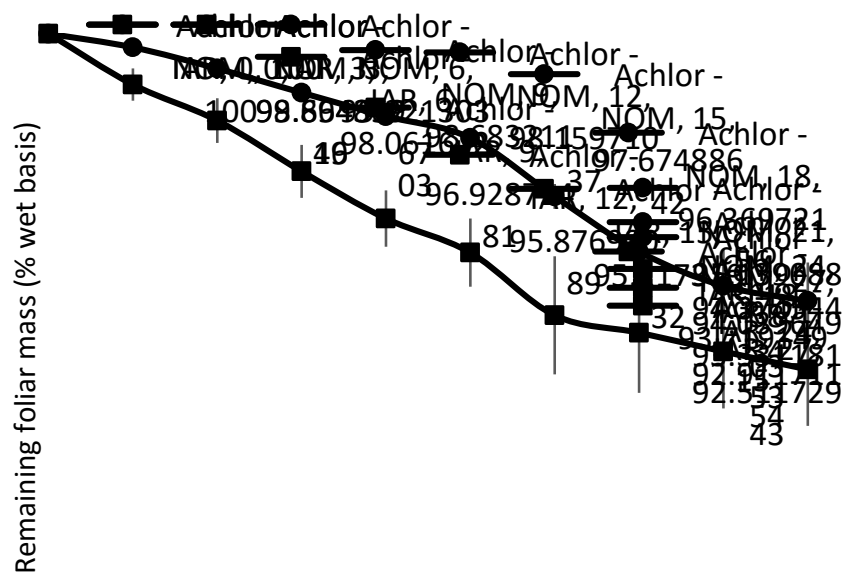

Time (days)

A. longa and $A$. chlorotica mixed culture

a)

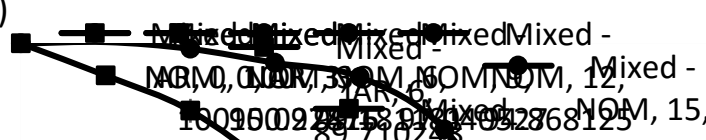

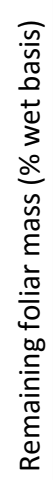

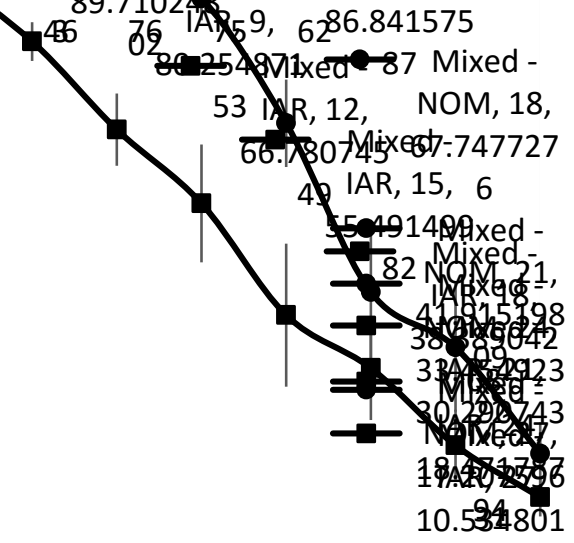

Time (days)
21 b)

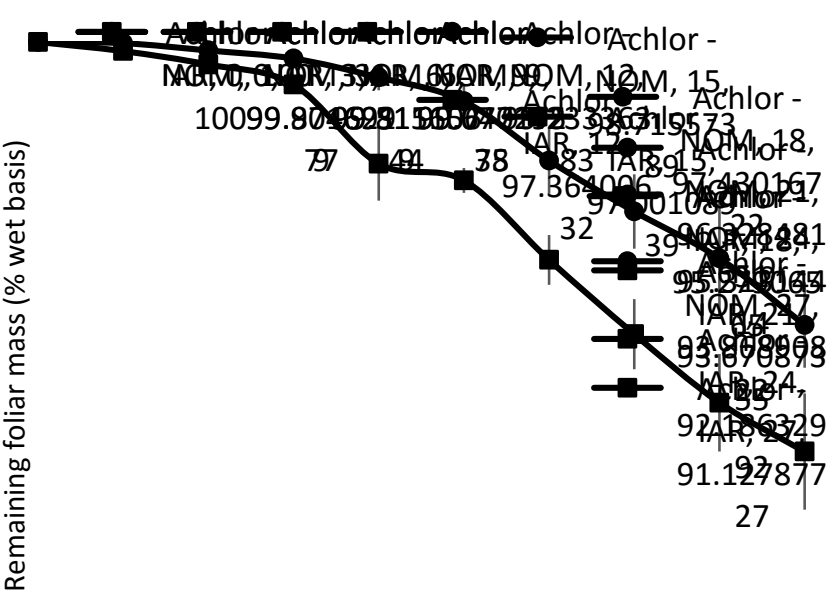

Time (days)

b)

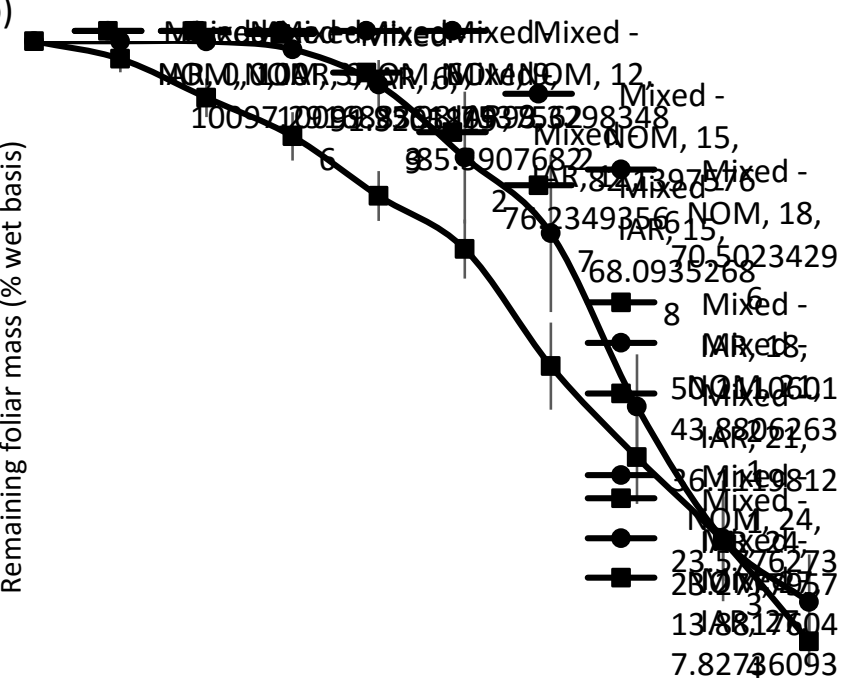

Time (days)

Figure 3. 
Table 3.

\begin{tabular}{lllll}
\hline \multirow{2}{*}{ Soil } & Earthworm Species & $\begin{array}{l}\text { Days taken to remove } \\
50 \% \text { total litter }\end{array}$ & \multicolumn{2}{l}{ Tree species } \\
\cline { 4 - 5 } & & A. cordata & A. platanoides \\
\hline Loam & A. longa & 15 & $13.9 \pm 5.9$ & $59.9 \pm 6.9^{* * *}$ \\
& A. chlorotica & Not achieved & $92.5 \pm 1.3$ & $94.0 \pm 0.9$ \\
& Mixed Sp. & 21 & $30.3 \pm 7.9$ & $41.9 \pm 10.5$ \\
& & & & \\
Reclaimed & A. longa & 15 & $38.3 \pm 3.3$ & $69.7 \pm 9.5^{*}$ \\
& A. chlorotica & Not achieved & $91.1 \pm 1.3$ & $93.9 \pm 0.9$ \\
& Mixed Sp. & 21 & $36.1 \pm 7.2$ & $43.9 \pm 8.0$
\end{tabular}

571 Student's t-test, $\mathrm{n}=5,{ }^{*} \mathrm{p}=<0.05,{ }^{* * *} \mathrm{p}=<0.001$. 
573 Table 4.

\begin{tabular}{llllll}
\hline \multirow{2}{*}{ Variable } & \multicolumn{2}{c}{ A. cordata } & & \multicolumn{2}{c}{ A. platanoides } \\
\cline { 2 - 3 } \cline { 5 - 6 } & Start & End & & Start & End \\
\hline Total N (\%) & 2.76 & 3.62 & & 1.59 & 2.27 \\
Total C (\%) & 52.60 & 54.90 & & 47.86 & 48.10 \\
C:N & 19.06 & 15.15 & & 30.16 & 21.15 \\
P (\%) & 0.13 & 0.14 & & 0.15 & 0.17 \\
Ca (\%) & 1.16 & 1.42 & & 1.98 & 2.38 \\
K (\%) & 0.95 & 0.84 & & 1.21 & 1.20 \\
Mg (\%) & 0.20 & 0.22 & & 0.22 & 0.26 \\
\hline
\end{tabular}

574

575 
$576 \quad$ Table 5.

Earthworm species Tree litter preference order
A. longa
ALg, FRe, BEp, ALc > EUn, ACp > ACps, CAs
A. chlorotica
ALg, FRe, BEp > EUn, ACps > ALc, ACp, CAs

577

578 
580 Table 1. Mean selected parameters $( \pm S E)$ of reclaimed soil and Kettering loam, prior to use 581 in the earthworm choice chamber experiment. ANOVA, $\mathrm{n}=3, * \mathrm{p}=<0.05, * * \mathrm{p}=<0.01$, *** $582 p=<0.001$.

583 Table 2. Initial and final (after 27 days) mean parameters of monocultures and mixed 584 cultures of the earthworms Aporrectodea longa and Allolobophora chlorotica in choice 585 chambers containing reclaimed soil or Kettering loam.

586 Table 3. Mean $( \pm \mathrm{SE}$ ) remaining Alnus cordata and Acer platanoides foliar material (\% from original mass, wet basis) in choice chambers containing monocultures or mixed cultures of the earthworms Aporrectodea longa and Allolobophora chlorotica and reclaimed soil or Kettering loam, at the point of $50 \%$ total foliar material removal. ANOVA, $n=5, * p=<0.05$, $* * * p=<0.001$.

Table 4. Chemical analysis of Alnus cordata and Acer platanoides foliar material at the start and termination of the earthworm choice chamber experiment (after 27 days), $n=1$.

Table 5. Tree litter and foliar preference by the earthworms Aporrectodea longa and Allolobophora chlorotica following Rajapaksha et al. (2013), updated with the results of this choice chamber experiment (in bold) as appropriate for Kettering Loam. Tree species: Alnus glutinosa (ALg), Fraxinus excelsior (FRe), Betula pendula (BEp), Eucalyptus nitens (EUn), Castanea sativa (CAs), Acer pseudoplatanus (ACps), Alnus cordata (ALc) and Acer 598 platanoides (ACp).

Figure 1. a) Empty choice chamber prior to use in an earthworm-based foliar preference experiment, b) detail of empty Eppendorf tube food vessel fixed to the wall of a choice chamber via drilled cap.

602 Figure 2. Prepared earthworm choice chambers, each containing Alnus cordata and Acer 603 platanoides foliar material and a soil treatment: a) Kettering loam, b) reclaimed soil (with 604 individuals of the earthworm species Allolobophora chlorotica on soil surface immediately 605 after addition).

606 Figure 3. Mean ( \pm SE) foliar mass remaining (\% wet basis) in choice chambers over a period 607 of 27 days. Earthworm species combinations as labelled, in (a) loam soil and (b) reclaimed 608 soil. Tree foliar species: Acer platanoides ( $\bullet$ ) and Alnus cordata (घ). 